\title{
Dynamic, mitotic-like behavior of a bacterial protein required for accurate chromosome partitioning
}

\author{
Philippe Glaser, ${ }^{1,3,5}$ Michaela E. Sharpe, ${ }^{1,5}$ Brian Raether, ${ }^{2}$ Marta Perego, ${ }^{2}$ Kari Ohlsen, ${ }^{2,4}$ and \\ Jeff Errington ${ }^{1,6}$ \\ ${ }^{1}$ Sir William Dunn School of Pathology, University of Oxford, Oxford, OX1 3RE, UK; ${ }^{2}$ Division of Cellular Biology, \\ Department of Molecular and Experimental Medicine, The Scripps Research Institute, La Jolla, California 92037 USA
}

The Bacillus subtilis spo0J gene is required for accurate chromosome partitioning during growth and sporulation. We have characterized the subcellular localization of Spo0J protein by immunofluorescence and, in living cells, by use of a spo0J-gfp fusion. We show that the Spo0J protein forms discrete stable foci usually located close to the cell poles. The foci replicate in concert with the initiation of new rounds of DNA replication, after which the daughter foci migrate apart inside the cell. This migration is independent of cell length extension, and presumably serves to direct the daughter chromosomes toward opposite poles of the cell, ready for division. During sporulation, the foci move to the extreme poles of the cell, where they function to position the oriC region of the chromosome ready for polar septation. These observations provide strong evidence for the existence of a dynamic, mitotic-like apparatus responsible for chromosome partitioning in bacteria.

[Key Words: Chromosome partitioning; sporulation; Bacillus subtilis; spo0I; mitosis; cell division]

Received December 23, 1996; revised version accepted March 20, 1997.

The mechanism by which bacterial chromosomes are equipartitioned into daughter cells at division has remained obscure despite decades of study (Hiraga 1993; Wake and Errington 1995). There are several reports of abrupt movement of bacterial nucleoids (Sargent 1974; Hiraga et al. 1990; Begg and Donachie 1991), suggesting the existence of an active partitioning machinery equivalent to the mitotic apparatus of eukaryotes. However, there are some difficulties in interpreting these results and van Helvoort and Woldringh (1994) have shown convincingly that unperturbed nucleoids move apart gradually and continuously during cell growth (van Helvoort and Woldringh 1994). The tendency to assume that the mechanisms of chromosome segregation in bacteria are distinct from those of eukaryotes stems mainly from the absence of obvious structures such as the cytoskeleton and the mitotic spindle. However, this might be attributable in part to the difficulty in resolving such structures in cells as small and tough as bacteria. Detection of mitotic-like activity is also hampered by the relatively unstructured state of the bacterial nucleoid and, particu-

\footnotetext{
Present addresses: ${ }^{3}$ Unité de Régulation de l'Expression Génétique, Institut Pasteur, 75724 Paris, France; ${ }^{4}$ Department of Biology, College of Sciences, San Diego State University, San Diego, California 92182-4614 USA.

${ }^{5}$ These authors contributed equally to this work.

'Corresponding author.

E-MAIL Jeff.Errington@path.ox.ac.uk; FAX 018-65-27-55-56.
}

larly, the absence of the extreme chromosome condensation of the mitotic metaphase. Nevertheless, there are good reasons for believing that active chromosome segregation mechanisms might exist in bacteria. First, the frequency of anucleate cell production is very low (Hiraga et al. 1989; Ireton et al. 1994), so the fidelity of partitioning is normally high. Second, several genes required for accurate partitioning have been identified (for review, see Hiraga 1993; Wake and Errington 1995). Unfortunately, most of the loci required for partitioning give relatively mild phenotypes or else they seem not to be specific for this process. Among the best characterized of these genes is $\operatorname{muk} B$. Mutations in $\operatorname{mukB}$ produce a significant increase in the level of anucleate cells produced in Escherichia coli (Niki et al. 1991). Moreover, the gene encodes a protein with some similarities to motor proteins such as myosins (Niki et al. 1991, 1992). However, null mutations in mukB are temperature-sensitive for growth, apparently for reasons independent of the partitioning defect, suggesting that the gene may have other unrelated functions (Niki et al. 1991). The SpolIIE protein of Bacillus subtilis does have a well-defined specific function, but it operates only under relatively specialized circumstances to move chromosomal DNA that has become trapped by a division septum $/ \mathrm{Wu}$ and Errington 1994; Sharpe and Errington 1995; Wu et al. 1995).

The spoOI gene of $B$. subtilis has recently been impli- 
cated in chromosome partitioning, both in vegetative dividing cells (Ireton et al. 1994) and during the asymmetric division of sporulation (Sharpe and Errington 1996). The gene is highly conserved in a diverse range of Gram + and Gram - bacteria, both in terms of primary amino acid sequence and in its position, close to the origin of chromosome replication foriC; Ogasawara and Yoshikawa 1992). It also shows striking similarity to a family of genes known to be required for partitioning of lowcopy-number plasmids in bacteria but whose mechanism of partitioning is unknown (Mysliwiec et al. 1991; Williams and Thomas 1992; Hiraga 1993; Hoch 1993). We have now characterized the subcellular localization of Spo0J and have uncovered a pattern of behavior indicating that Spo0J participates in a dynamic, mitotic-like mechanism driving active separation of sister chromosomes. Similar observations of SpoOJ localization in $B$. subtilis (Lin et al. 1997) and of the equivalent protein in Caulobacter crescentus (Mohl and Gober 1997) have been made elsewhere independently.

\section{Results}

\section{Localization of Spo0I by immunofluorescence microscopy}

To study the subcellular localization of Spo0), we purified the $B$. subtilis protein, raised a polyclonal antiserum, and used affinity purification to obtain highly specific antibodies. This specificity was confirmed by Western blotting (Fig. 1A). A single band of mobility expected for the predicted Spo0) protein was detected in vegetative cells of $B$. subtilis (lane 1). This band was absent from a spo0/ null mutant (lane 2) and it was replaced by a slower migrating band in a strain in which spoOJ was fused to a reporter gene (lane 3). Immunofluorescence microscopy (IF) with the specific antibodies revealed that the Spo0I protein was localized in a number of discrete foci in vegetatively growing cells (Fig. 1, B-D). (No signal was detected in cells of a spoO/ deletion mutant; data not shown.) At least one focus was detected in almost all of the cells. The distribution of the foci appeared to be orderly, with most being located close to the outer margins of the nucleoid, as visualized by staining the DNA with DAPI (Fig. 1C,D). Note that the DAPI stain is shown in red, rather than its natural blue color, to make recognition of overlaps in the fluorescent signals (yellow) clearer. In many cells the foci located at one or both ends of the nucleoid seemed to consist of an adjacent pair of fluorescent spots (indicated by thick arrows). After the cells were induced to sporulate, the characteristic elongation of the nucleoid, associated with formation of the axial filament (Bylund et al. 1993), appeared to be accompanied by displacement of the SpoOJ foci to the extreme opposite poles of each cell (Fig. 1, E-G). Cells with nucleoids in this state were detected from $45 \mathrm{~min}$ after the onset of sporulation, as described previously by Hauser and Errington (1995). Such cells always showed Spo0J foci in extreme polar positions. It therefore appears that the shift of the Spo0j foci to the poles is associated closely with formation of the axial filament.

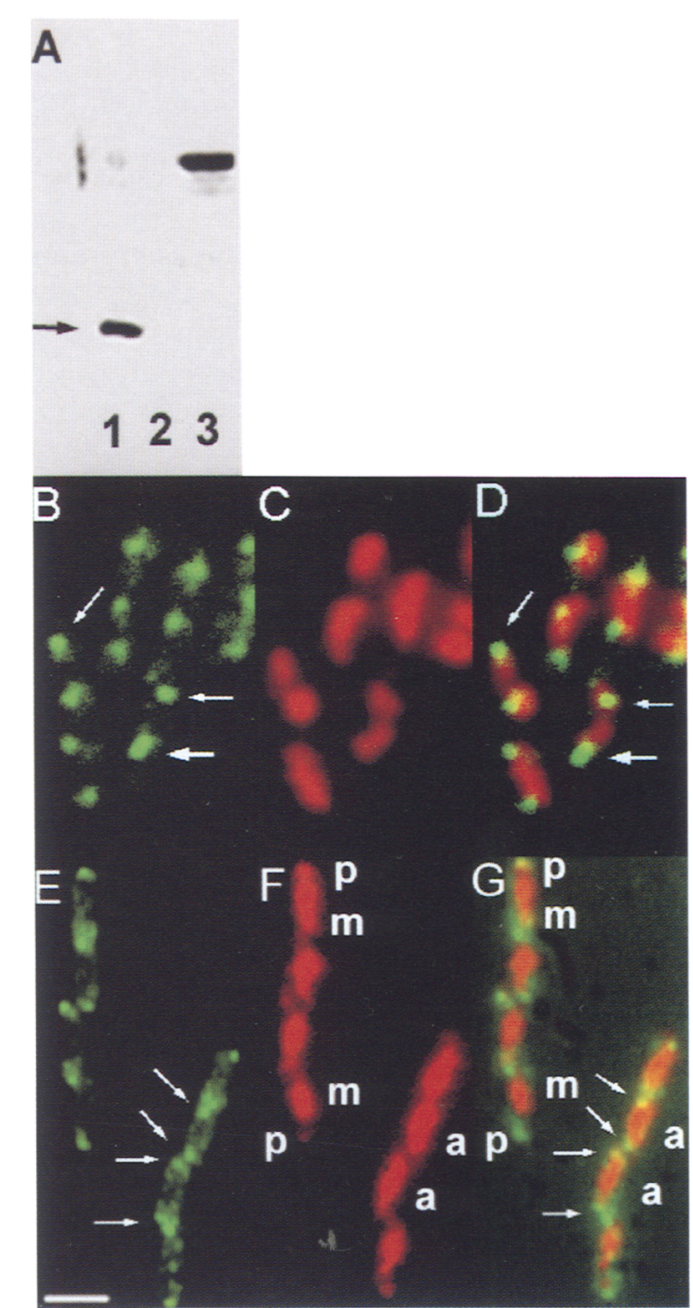

Figure 1. Localization of SpoOJ in B. subtilis cells by IF. $(A)$ Western blot, performed after SDS-PAGE $(12 \%)$ and electrotransfer, demonstrating the specificity of the anti-Spo0J antiserum and the increase in molecular weight of Spo0j fused to GFP. (Lane 1) Wild-type (strain SG38); (lane 2) spo0I null mutant (strain 1407); (lane 3) spo0J-gfp (strain 1510). The arrow indicates the position of full-length Spo0J protein. $\{B-G\}$ Immunofluorescence micrographs showing the detection of discrete foci of Spo0J protein in growing cells (CH medium) $(B-D)$ and 140 min after initiation of sporulation by resuspension $(E-G)$. The cells were stained for Spo0J protein (green channel; $B, E$ ), for DNA with DAPI (red channel; $C, F\}$, and merged $(D, G) .(F, G)$ Two kinds of sporulating cells can be distinguished by their nucleoid state: early preseptation cells with an extended nucleoid [axial filament (a)], and septate cells with distinct prespore (p) and mother cell $(\mathrm{m})$ nucleoids. Thin arrows in $B$ and $D$ indicate single foci and the thick arrow indicates a pair of touching foci. Arrows in $E$ and $G$ indicate the typical bipolar localization of Spo0J foci in cells at the axial filament stage. Scale bar, $2 \mu \mathrm{m}$.

\section{Visualization of SpoOI foci with a GFP fusion}

Although the IF images pointed to there being a highly organized distribution of Spo0J, the precise pattern, particularly in relation to cell cycle progression, was diffi- 
cult to deduce because of the relatively poor preservation of cellular structures by the IF method. To overcome this problem, we turned to a reporter system based on green fluorescent protein (GFP), which could be used to study the localization of the protein in living cells. The spoOf$g f p$ fusion construct was introduced into the $B$. subtilis chromosome by homologous recombination, replacing the wild-type gene, to give strain 1510 . Western blot analysis (Fig. 1A) showed that a full-length fusion protein was being made, with no sign of degradation. In preliminary experiments with cells producing the Spo0JGFP fusion protein, the cellular localization of the fluorescence was reminiscent of that obtained with IF. However, the images were difficult to interpret, partly because of technical problems with the methods used, and partly because the Spo0J-GFP fluorescent foci were visible only for a short period after mounting the cells, apparently because the cells die on polylysine-coated microscope slides. However, we found that by placing the cells on a thin film of agarose (see Materials and Methods), far superior results were obtained, not only for Spo0I but also for various other GFP fusions that we have studied. Moreover, the cells remained viable for much longer periods, allowing time-lapse images to be obtained (see below). As for other fusions we have studied previously (Lewis and Errington 1996), we found that the signal intensity and degree of localization were much better at $30^{\circ} \mathrm{C}$ than at $37^{\circ} \mathrm{C}$.

Microscopic examination of a sample of growing cells immobilized by the new procedure (Fig. 2A) revealed a pattern of fluorescence clearly reminiscent of that revealed by IF, but the contrast was better and the cell outlines were readily discernible by phase-contrast microscopy (Fig. 2B). To confirm that the pattern was directed by the SpoOJ moiety of the fusion we constructed a similar fusion lacking the final 18 amino acids of SpoOJ (in strain 1517), which we hoped would eliminate targeting of the protein. Accordingly, this fusion protein showed an unlocalized distribution (Fig. 2C,D), even though Western blots showed that the truncated protein accumulated to normal levels (data not shown). It therefore seems that the carboxy-terminal region of SpoOI is required for targeting of the protein to discrete foci.

\section{Behavior of a Spo0J-GFP fusion during cell cycle progression}

Images such as that of Figure $2 \mathrm{~B}$ suggested a clear relationship between cell length and the number of discrete Spo0J-GFP foci. Sister B. subtilis cells tend to remain attached to each other for a relatively extended period following formation of the division septum (Holmes et al. 1980), so many of the rods in Figure 2B actually contained two or more septated compartments. Clearly, however, the shortest rods, presumably representing newly separated cells (e.g., cell labeled a), or rods with a clear indentation indicating that they were about to separate (e.g., the pair of cells labeled b), generally contained two foci. The two foci were usually well spaced, with one near to each cell pole. The longer rods tended to contain three (e.g., c) or, more usually, four (d) foci. Often

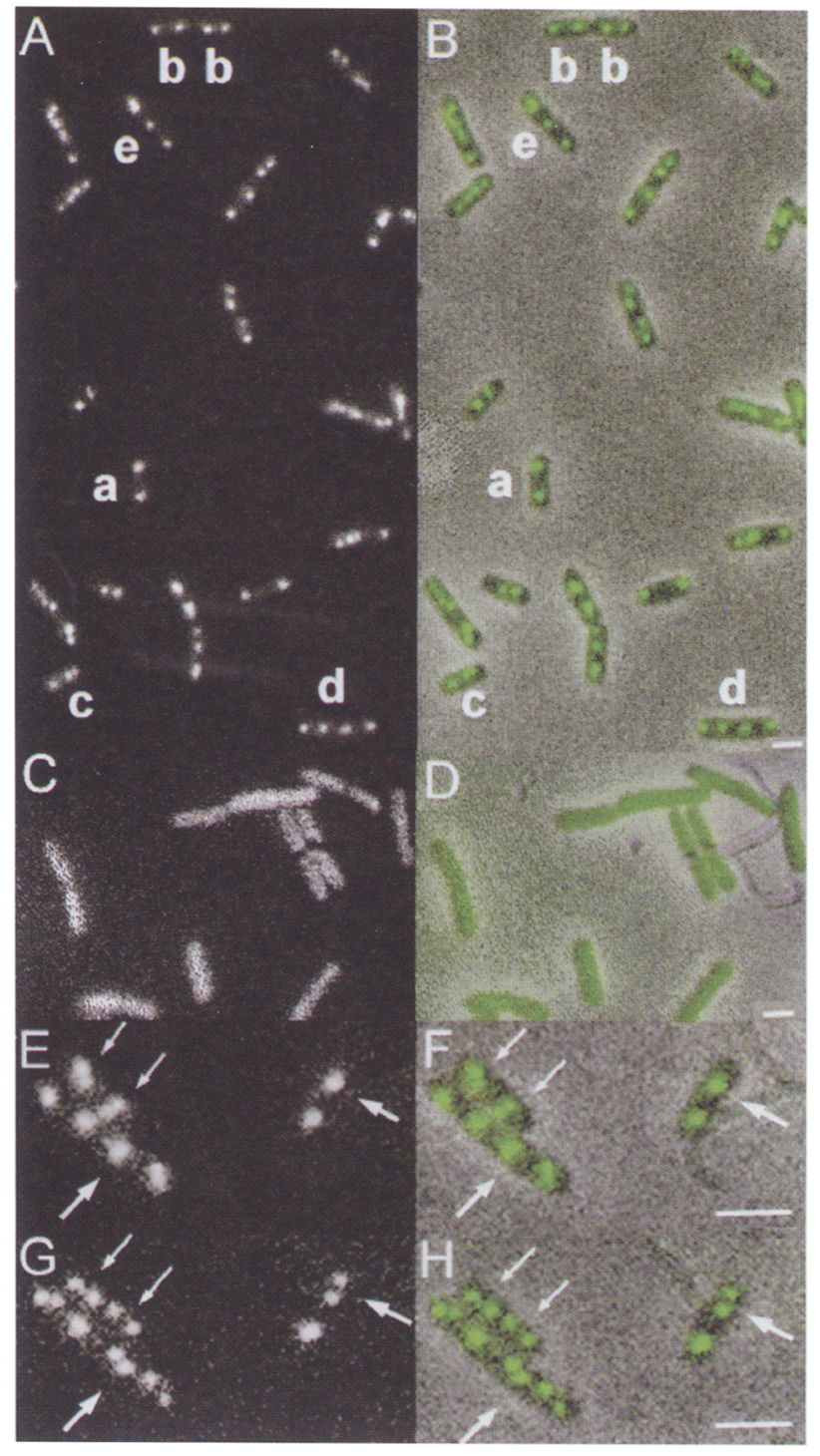

Figure 2. Genesis and behavior of Spo0J-GFP foci during cell cycle progression. $(A, C, E, G)$ Fluorescence images showing the distribution of Spo0J-GFP foci. $(B, D, F, H)$ The same images in green overlaid on phase-contrast images of the same field of cells. $(A, B)$ Spo0T-GFP in growing cells (SMMX medium) of $B$. subtilis strain 1510. Examples of cells with different patterns of Spo0J-GFP foci are labeled a-e (see text). $(C, D)$ Diffuse GFP distribution in strain 1517, which is similar to 1510 except that GFP is fused to a truncated form of Spo0 lacking 18 carboxyterminal codons. $(E-H)$ Duplication and migration of Spo0JGFP foci in individual growing cells (note higher magnification). Strain 1510 was immobilized on agarose and an image was taken immediately $(E, F)$, then of the same field of cells $30 \mathrm{~min}$ later $(G, H)$. Thin arrows indicate examples of foci that duplicated during the period of incubation, and thick arrows indicate examples of pairs of foci that appeared to move apart along the long axis of the cell. Scale bars, $2 \mu \mathrm{m}$.

the foci were regularly spaced in these cells (e.g., d) but in some cells a pair of foci were nearly touching or there was a single bright, elongated focus, corresponding to two overlapping foci or perhaps a single dividing focus (e.g., cell e). 


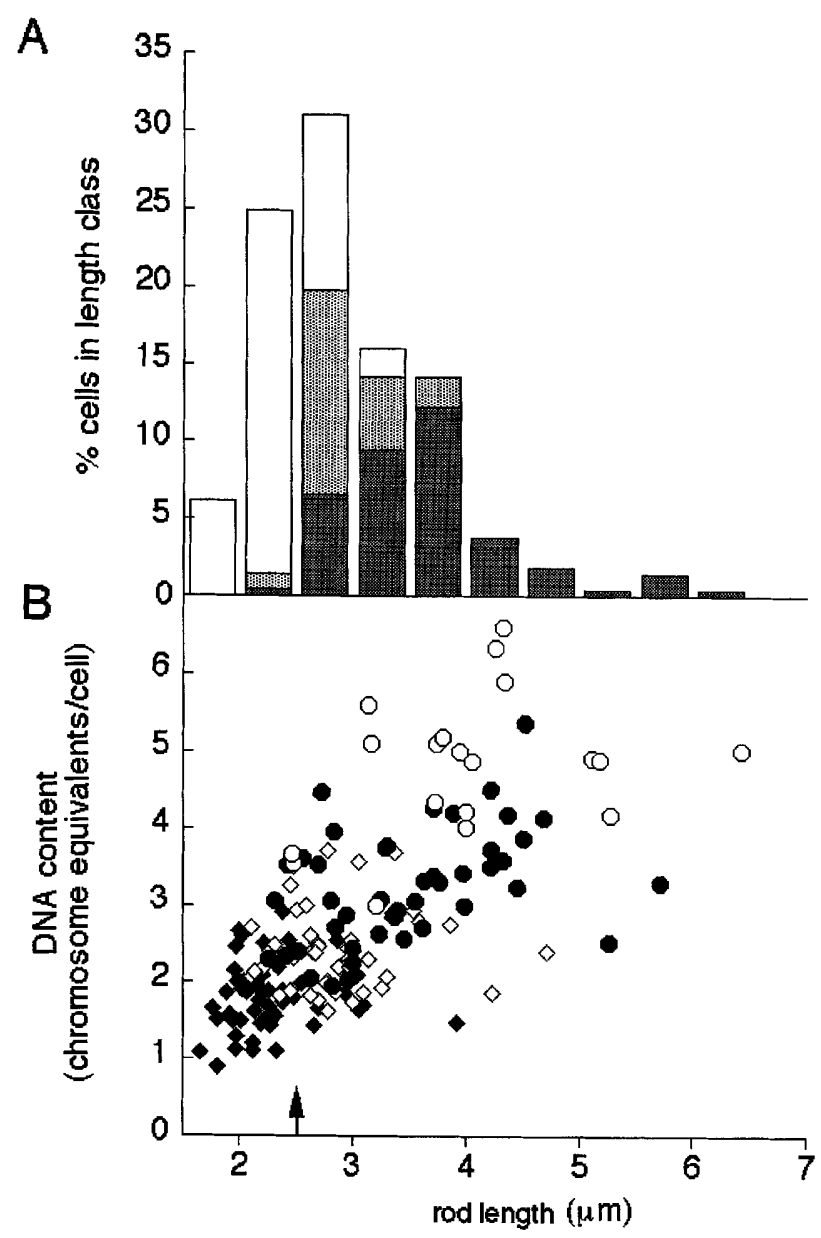

Figure 3. Analysis of the distribution of Spo0J-GFP foci vs. cell cycle progression. $(A)$ Rod length-frequency distributions for 213 cells viewed as illustrated in Fig. 2B, with a breakdown of the numbers of Spo0J-GFP foci in each length class. (Open bar) 2 spots; (stippled bar) 3 spots; (shaded bar) $\geqslant 4$ spots. $(B)$ Length/ DNA content plot for 155 cells from the same culture fixed with ethanol and scored for DNA content and presence of division septa. Within each length class the rods were divided into four classes on the basis of comprising either a single/mononucleate ( $\bullet$ cell, a single/binucleate cell $(\diamond)$, a twin/mononucleate cell (O), or a twin/binucleate cell (O). The arrow shows the average rod length at initiation of DNA replication.

Counting of the foci in relation to cell length revealed that in this medium (SMMX; see Materials and Methods) their numbers increased from two to three or four per cell at a length of $-2.5 \mu \mathrm{m}$; Fig. $3 \mathrm{~A}$, indicating that the foci were replicating in concert with cell growth. (The cells scored as having three foci would arise either through asynchrony in the cell cycle progression of sister cells, or more likely, by scoring pairs of adjacent or overlapping foci as a single focus.) Unfortunately, it was technically difficult to directly determine when replication of the Spo0J foci occurred relative to cell cycle progression because the GFP foci were difficult to see in cells that had been fixed to allow visualization and quantitation of the DNA and the division septa. We therefore analyzed cell cycle parameters in a duplicate sample of ethanol-fixed cells. As shown in Figure 3B, newborn cells had a length of $-2 \mu \mathrm{m}$ and contained a single partially replicated chromosome (DNA content one to two chromosome equivalents). When the cells reached a length of $-2.5 \mu \mathrm{m}$, they became binucleate, indicating that termination of DNA replication had occurred. As expected for cells growing at this rate (generation time approximately equal to the DNA replication time), a new round of DNA replication was initiated at about the same time (arrow in Fig. 3B), to produce cells with a DNA content of $>2$ chromosome equivalents. Septation occurred at $\sim 3 \mu \mathrm{m}$, to produce twin cells, each with a single replicating nucleoid. So, the longer rods visible in Figure 2 actually comprise two cells connected at the recently completed division septum. Cell separation (which is relatively variable in $B$. subtilis; Holmes et al. 1980) followed at an average length of $\sim-5 \mu \mathrm{m}$. Comparison of panels $A$ and $B$ of Figure 3 shows that the duplication of the SpoOJGFP foci occurs at about the same time that initiation or termination of rounds of DNA replication occur in SMMX medium.

To test more rigorously for a link between a specific cell cycle event and the duplication of Spo0J-GFP foci, the average number of Spo0J-GFP foci per cell was determined in cells cultured at a range of different growth rates. Because the time taken to replicate the chromosome (the $\mathrm{C}$ time) is relatively fixed, bacterial cells compensate for an increasing growth rate by having multiple ongoing rounds of DNA replication. The number of copies of the origin of replication per cell therefore increases (in the growth media used, from just over two copies per cell, to more than six copies per cell; Table 1). In all cases the average number of SpoOJ foci per cell was just less than the calculated number of copies of oriC per cell, indicating a clear relationship between the initiation of DNA replication and the duplication of Spo0J foci.

Table 1. Relative copy numbers of oriC and Spool foci at different growth rates

\begin{tabular}{lccc}
\hline Medium & Growth rate & $\begin{array}{c}\text { Mean no. Spo0J } \\
\text { foci per cell }^{\mathrm{b}}\end{array}$ & $\begin{array}{c}\text { Mean no. oriC } \\
\text { copies per cell }^{\mathbf{c}}\end{array}$ \\
\hline CHG & 30 & 6.0 & 6.2 \\
CH & 40 & 4.4 & 4.7 \\
TS & 58 & 3.2 & 3.6 \\
SMMX & 66 & 2.5 & 2.9 \\
S & 73 & 1.7 & 2.1 \\
\hline
\end{tabular}

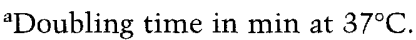

${ }^{b}$ The GFP foci in three microscopic fields $(-100$ cells) were counted, and the total cell length was measured, to give GFP foci per unit length. The average number of cells per unit length was determined by measurements on a parallel sample of fixed cells (Hauser and Errington 1995). From this, the average number of foci per cell was calculated. The cells were grown at $30^{\circ} \mathrm{C}$. ${ }^{c}$ Derived from the cell length/frequency distributions using the cell length at initiation of DNA replication la constant of $\sim 1.2$ $\mu \mathrm{m}$ per copy of oriC, to be described in full elsewhere (P.M. Hauser et al., unpubl.; see also Fig. 3; Hauser and Errington 1995). Measurements were done at $37^{\circ} \mathrm{C}$, or $30^{\circ} \mathrm{C}$ for SMMX. The dimensions and DNA content of cells grown at $30^{\circ} \mathrm{C}$ and $37^{\circ} \mathrm{C}$ appear indistinguishable, so we assume that the copy number for oriC is not affected significantly by the temperature. 


\section{Duplication and movement of SpoOI foci in living cells}

One way to test directly the inference that the Spo0JGFP foci undergo systematic duplication and separation during the cell cycle would be to follow the fate of individual foci in living cells. We found that the agarose immobilization method for observing GFP allowed continued cell viability for a relatively protracted period $\mid>1$ hr), and even a limited amount of cell growth on the microscope stage. We therefore followed the fate of individual cells incubated for $30 \mathrm{~min}$ or more on the microscope stage. During this period cell growth was negligible $(\sim 3 \%$ of cell length for 62 measured rods) and the localization of Spo0J-GFP in discrete foci was retained unchanged in almost all of the cells. However, two kinds of change did occur in about $20 \%$ of the cells (presumably, only a small proportion of the cells in the asynchronous population would be at the appropriate point in the cell cycle). First, in cells that initially had a pair of closely apposed foci, the foci had clearly moved apart 30 min later (Fig. 2, E-H, thin arrows), so that they came to occupy positions that would be near to the opposite poles of the new daughter cells after median division. Second, new foci appeared (thick arrows), usually in the form of a pair of nearly adjacent foci close to the position of a pre-existing focus. These observations strongly suggest that new foci arise by duplication of pre-existing foci and that newly replicated foci move apart to give rise to the regularly spaced foci in longer rods. Moreover, they also show that subcellular movement of the SpoOJ foci is independent of growth of the cell envelope. By incorporation of growth medium into the agarose immobilizing the cells, significant cell growth could be maintained. In these experiments, similar duplication and separation of the Spo0J foci was detected, indicating that this behavior was not an artifact brought on by stasis (data not shown).

Two kinds of experiments were done to test whether the behavior of Spo0J foci was dependent on DNA replication. First, we treated cells with tetracycline to inhibit protein synthesis and therefore block the initiation of DNA replication. In these cells, the Spo0J-GFP foci remained visible for protracted periods of observation, just as in untreated cells, but duplication of the Spo0J foci was not detected (data not shown). Second, we transformed the spo0I-gfp fusion into a thymine auxotroph, to generate strain 1723. Thymine deprivation was used to block DNA synthesis (Donachie 1971) and the effects on SpoOI localization were examined. As shown in Figure $4 \mathrm{~B}$, inhibition of DNA replication resulted in the formation of elongated cells with single partially replicated nucleoids located approximately mid-cell, and the ends of the cells were devoid of DNA to a greater or lesser extent. This state arises because the cells continue to elongate in the absence of DNA synthesis, and the presence of an incomplete nucleotide at the mid-cell is inhibitory to cell division (McGinness and Wake 1979; Sharpe and Errington 1995). In contrast, in the control culture (Fig. 4D), the DNA more or less filled the short cells, as expected. At the slow growth rate sustained by the minimal medium used (SMMX), the incompletely

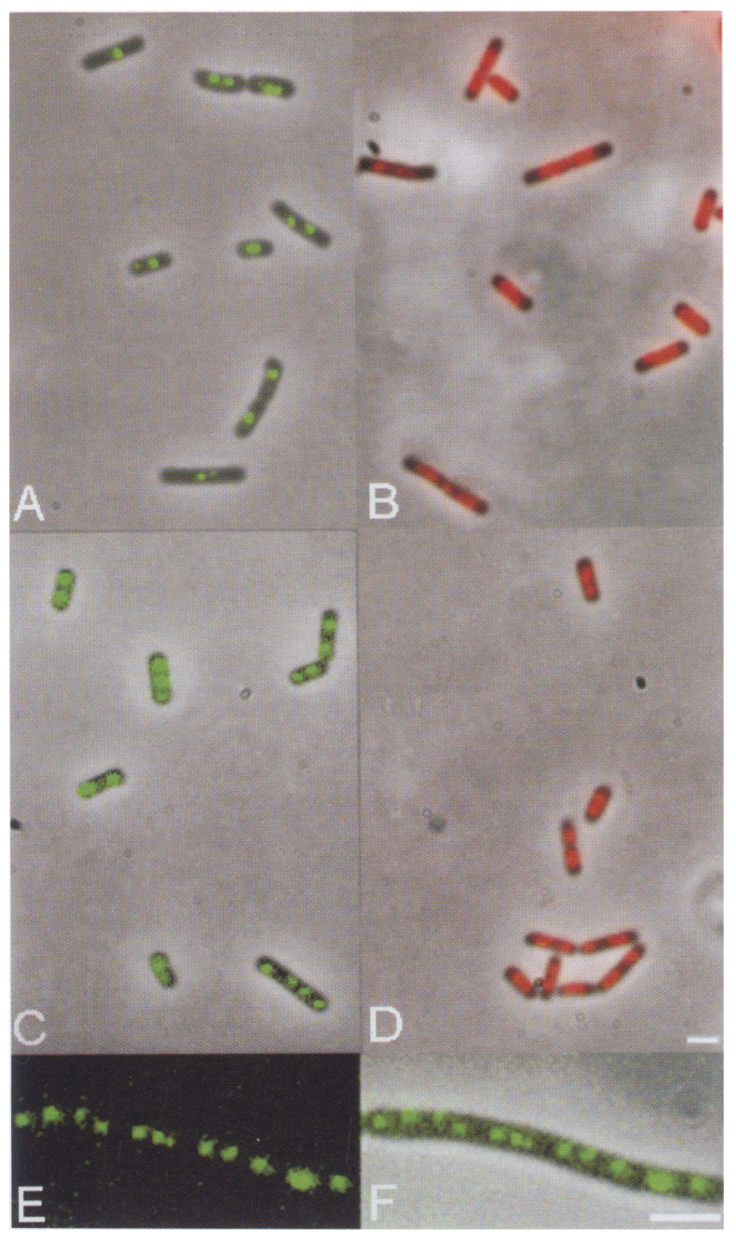

Figure 4. Effects of inhibition of DNA synthesis $(A-D)$ or cell division $(E, F)$ on the behavior of Spo0J-GFP foci. $(A-D)$ A culture of strain 1723 (thy $A$ spoOJ-gfp) was grown in SMMX with $(C, D)$ or without $(A, B)$ thymine. Deprivation of thymine causes an immediate block in DNA synthesis. $(A, C)$ Overlays of phasecontrast and GFP fluorescence images of unfixed cells. $(B, D)$ DAPI images of fixed cells. $(E, F)$ Strain 1408 (divIB::spc spo0)$g f p \mid$ was grown in SMMX at $37^{\circ} \mathrm{C}$ to induce formation of elongated aseptate filaments. $|E\rangle$ GFP image ; $(F)$ overlay of GFP and phase-contrast images.

replicated nucleoids in the thymine-starved culture should contain either one or two copies of oriC, depending on whether they were undergoing DNA replication. Figure $4 \mathrm{~A}$ accordingly shows that these cells contained one or two centrally positioned Spo0J foci, consistent with the foci being associated with chromosomal oriC regions. Weak GFP fluorescence was observed in fixed cells, and in such preparations we found that all visible Spo0I foci were associated with the DNA and did not occur in the nucleoid-free regions.

Finally, we examined whether positioning of the foci was, like nucleoid partitioning (see Wake and Errington 1995), independent of septum formation. A divIB mutation, which causes septation to be partially inhibited at $37^{\circ} \mathrm{C}$ (Beall and Lutkenhaus 1989), was transformed into the spo0J-gfp strain. As shown in Figure $4(\mathrm{E}, \mathrm{F})$, the Spo0J- 
GFP foci were distributed throughout the length of the filamentous cells, with a local patterning similar to that of the short wild-type cells.

\section{Discussion}

The work described here was prompted by recent new insights into chromosome partitioning during spore formation in B. subtilis. During sporulation, the cell cycle machinery is modified so as to divert the division septum from its normal central position to a highly asymmetric position near to one of the cell poles. Studies of spoIIIE mutants showed that the chromosome has a specific orientation at the time of asymmetric division, such that a segment of DNA centered approximately on oriC is located close to the pole of the cell (Wu and Errington 1994). This suggested the existence of a centromere-like region located near oriC. We recently showed that in spooI mutants the specificity of the segment trapped is relaxed, indicating that the SpoOI protein is required for proper positioning of the centromere in the pole of the cell (Sharpe and Errington 1996). Our present finding that SpoOJ protein localizes to the extreme poles of the cell during sporulation, just as the nucleoid takes on its extended axial filament state, would be consistent with a direct role in determining centromere localization.

Several Spo0J-like proteins encoded by plasmids are required for plasmid partitioning, although precisely how they work is not yet understood, nor has their subcellular localization been determined. It is clear, however, that they act by binding to a specific cis-acting site, which is required for partitioning and lies adjacent to or near the gene encoding the partitioning function (Williams and Thomas 1992; Hiraga 1993). A related chromosomally encoded protein in C. crescentus is also capable of binding to a site adjacent to its gene (Mohl and Gober 1997). It is therefore likely that Spo0f also binds directly to DNA, although a specific binding site near the spoOI locus has so far eluded detection; displacement of a 4-kb segment of DNA containing the spoOI gene to a distant chromosomal location does not significantly influence the orientation of the chromosome mediated by Spo0J at the beginning of sporulation (L.J. Wu and J. Errington, unpubl.). We estimate that there are $\sim 1500$ molecules of wild-type SpoOJ per cell (P. Glaser and J. Errington, unpubl.), suggesting that the distinct foci we have observed contain many Spo0I molecules. We therefore favor the idea that the protein effects partitioning by binding at multiple sites in the oriC region of the chromosome, though we cannot yet exclude the possibility that it interacts with DNA indirectly.

The behavior of the Spo0I foci as revealed by the above experiments is summarized in schematic form in Figure 5. The regular cyclic duplication of SpoOJ foci in vegetative cells was consistent with the known role for this protein in chromosome partitioning of vegetative cells (Ireton et al. 1994). At a range of different growth rates, the average number of SpoOJ foci was always just less than the number of copies of oriC. Furthermore, the in-

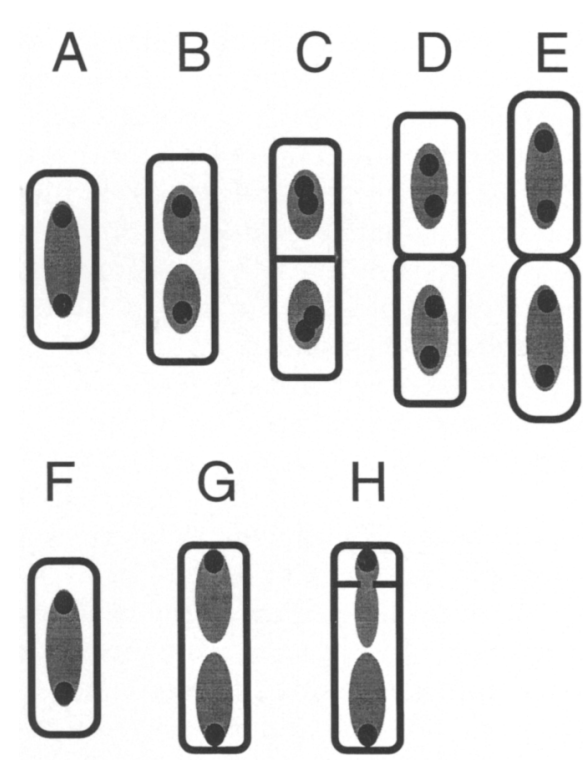

Figure 5. Schematic summary of the behavior of Spo0J foci during cell cycle progression in vegetative cells and during sporulation. $(A-E)$ Intermediate stages in a typical cell cycle, modeled from the data in Fig. 3 and accounting for the observed behavior of Spo0J foci illustrated in Figs. 1 and 2. The lightshaded ovals represent nucleoids and darker-shaded circles represent SpoOJ foci. The shortest rods, representing newly separated cells $\{A\}$, have a single partially replicated chromosome and SpoOJ foci near both poles. Termination of the ongoing round of DNA replication $(B)$ results in the transition from a mononucleate cell to one with two separated nucleoids (binucleate). (C) The cell then forms a division septum and at about the same time new rounds of DNA replication are initiated at oriC in each daughter cell. Duplication of the Spo0J foci occurs at or soon after this time. $(D)$ The newly divided Spo0J foci (each probably associated with a copy of the newly replicated oriC region) then move apart, presumably helping to ensure segregation of the sister chromosomes. Cell separation $(E)$ results in conversion of a single long rod with four approximately equally spaced SpoOJ foci to two short rods each with two foci. $(F-H)$ Extreme polar localization of SpoOJ foci at the onset of sporulation. (F) A cell about to initiate sporulation contains a single partially replicated chromosome (Hauser and Errington 1995) as in $A$. (G) Soon afterwards, the round of DNA replication is completed and the chromosome takes on an extended configuration, known as the axial filament (Bylund et al. 1993). This is accompanied by movement of the SpoOJ foci to the extreme poles of the cell (Fig. 1G). $(H)$ The polar localization of the oriC region of the chromosome, mediated in part by SpoOJ (Sharpe and Errington 1996), ensures that part of the upper chromosome is bisected by the polar division septum that generates the separate prespore and mother cell compartments.

crease in numbers of foci appeared to coincide with, or just to follow, the initiation of new rounds of DNA replication. When reinitiation of DNA replication was blocked, no new foci were detected. When DNA synthesis was completely inhibited (Fig. 4), the Spo0J foci remained associated with the DNA in the cell and their numbers were again consistent with them being associated with the oriC regions of the chromosomes. All of these observations suggest that the Spo0J foci represent 
protein complexes or aggregations that are associated with sequences in or near the origin of DNA replication. We suggest that during the early stages of a new round of replication, the two new copies of the oriC region each become associated with new complexes. Individual proteins within the original complexes might be segregated into the daughter complexes by remaining associated with a specific strand of DNA during replication, or they could be completely displaced from the DNA and then reassociate with the nascent daughter DNA duplexes.

Time-lapse experiments such as those of Figure 2 strongly support the idea that new foci arise by duplication of pre-existing foci. They also show that sister foci can move away from each other and that this subcellular migration occurs independent of cell growth. To our knowledge, these results represent the first direct demonstration of rapid organized movements of organellelike protein complexes inside bacterial cells. The most likely explanation for such behavior would be that the cells possess force-generating motor proteins and perhaps cytoskeletal elements, analogous to microtubules or microfilaments, as in eukaryotic cells. The Spo0J protein may provide a handle with which these putative functions can be isolated and studied.

Most previous models for chromosome partitioning in bacteria have assumed that chromosome movement is coupled in some way to growth of the cell envelope (for review, see Wake and Errington 1995), in a manner quite dissimilar from the dynamic mitotic apparatus of eukaryotic cells. However, on the basis of our results, it appears that the Spo0J protein may contribute to an assembly analogous to the eukaryotic kinetochore, which attaches the centromere to the mitotic spindle (for review, see Hyman and Sorger 1995). It may be that chromosome segregation in bacterial cells has much more in common with the process of mitosis than had been thought previously.

\section{Materials and methods}

Bacterial strains and media

All of the B. subtilis strains used were isogenic with SG38 trpC2 (Errington and Mandelstam 1986), so all media were supplemented with tryptophan $(20 \mu \mathrm{g} / \mathrm{ml})$. Strain 1407 was derived by transforming the $\Delta$ spo0/::spec mutation from AG1468 (Ireton et al. 1994) into SG38. Other strain constructions are described below. Sporulation was induced by growth in a hydrolyzed casein medium $(\mathrm{CH})$, followed by resuspension in a starvation medium (Sterlini and Mandelstam 1969; Partridge and Errington 1993). CHG was $\mathrm{CH}$ medium containing $0.5 \%$ glucose; TS and S media were as described by (Karamata and Gross 1970); SMMX was SMM of Karamata and Gross (1970) containing glucose $(0.4 \%), \mathrm{MgSO}_{4}(1 \mathrm{~mm})$, and ammonium iron (III) citrate $(0.04 \mu \mathrm{M})$.

\section{Purification of SpoOI protein}

The Spo0J-coding sequence was amplified by PCR from the chromosome of strain JH642 (trpC2 phe1), using flanking oligonucleotides, and cloned in the BamHI site of the pET16b expression vector (Novagen) giving pET16b0JB. After transforma- tion of pET16b0JB into the $E$. coli expression host strain BL21(DE3) (Novagen), 5 liters of culture was grown in LuriaBertanni medium containing $100 \mu \mathrm{g} / \mathrm{ml}$ ampicillin. When the culture reached an $\mathrm{OD}_{600}$ of 0.7 , the cells were induced with 2 mM IPTG and incubation was continued at $37^{\circ} \mathrm{C}$ for an additional $2.5 \mathrm{hr}$ before harvesting. The cell pellet was resuspended in $100 \mathrm{ml}$ of buffer $\mathrm{A}(50 \mathrm{~mm}$ potassium phosphate at $\mathrm{pH} 6.5$, $300 \mathrm{~mm} \mathrm{NaCl}, 1 \mathrm{~mm} 2$-mercaptoethanol, $0.1 \mathrm{~mm}$ PMSF, $20 \mathrm{~mm}$ imidazole!, sonicated for six cycles of 30 -sec bursts, and centrifuged for $30 \mathrm{~min}$ at $15,000 \mathrm{rpm}$ in a Sorvall SS34 rotor. The cell extract was mixed with $10 \mathrm{ml}$ of Qiagen Ni-NTA agarose for 1 $\mathrm{hr}$ at $4^{\circ} \mathrm{C}$ with shaking. The resin was loaded into a 3-cm-diameter column and washed with buffer A. The Spo0J protein was recovered by step elution using $50 \mathrm{ml}$ of buffer A containing first $50 \mathrm{~mm}$ imidazole, then $100 \mathrm{~mm}$ imidazole, and finally 200 $\mathrm{mM}$ imidazole (final concentrations).

\section{Antibodies and IF}

A rabbit polyclonal antiserum was raised by standard procedures (Harlow and Lane 1988). The antibodies were affinity purified as described by Reznekov et al. (1996), using $4.5 \mathrm{M} \mathrm{MgCl}_{2}$ as eluant. The final purified antiserum was used at dilutions of 1:100 for IF and 1:1000 for Western blot analysis. Fixation, permeabilization, and IF staining of the cells were performed as described previously (Pogliano et al. 1995; Lewis et al. 1996; Reznekov et al. 1996). Images were grabbed as described previously (Lewis et al. 1996), except that Figure 1B,C, and D, were taken with a Sys $2000,1536 \times 1024$ pixel ( $9 \mu \mathrm{m}$ pixel pitch) cooled CCD camera (Digital Pixel). The 12-bit images from this camera were processed with IP Lab Spectrum 3.1a software (Signal Analyticals, Vienna, Virginia). Exposure times were $2 \mathrm{sec}$ for IF and $0.5 \mathrm{sec}$ for DAPI.

\section{Construction and analysis of spo0J-gfp fusions}

Plasmid pSG1201 was constructed by cloning a 283-bp carboxyterminal-coding fragment of the spoOJ gene, as a HindIII-EcoRI fragment, into plasmid pSG1137 (Lewis and Errington 1996). The EcoRI site replaced the TAA stop codon of spoOI with a GAA glu codon. In preliminary experiments, this fusion junction was found to impair the function of the SpoOJ moiety las judged by a reduced sporulation frequencyl, so a linker encoding the following 15 amino acids, L P G P E L P G P E L P G P E, was introduced at the EcoRI site. Transformation of the resulting plasmid (pSG1517) into the chromosome of B. subtilis strain SG38 gave strain 1510 , which sporulated at near wild-type levels. The pattern of fluorescent foci obtained with strain 1510 was indistinguishable from that of the sporulation-deficient strain containing the spoOI-gfp fusion with no linker \{results not shown).

A $g f p$ fusion to a carboxy-terminally truncated form of spoOI (lacking the last 18 codons) was made by integration of plasmid pSG1223 into strain SG38, to form strain 1517. pSG1223 was constructed in a similar way to pSG1201, except that the amplified spoo/ DNA was digested by StuI and at an artificial EcoRI site created by changing the 264th TTT Phe codon of spoOI to the synonymous TTC codon. This 780-bp long DNA fragment was cloned into plasmid pSG1137 (Lewis and Errington 1996) digested with EcoRV and EcoRI.

Strain 1510 cells grown at $30^{\circ} \mathrm{C}$ were spread and immobilized on agarose-coated microscope slides as follows. Two microliters of a $1.2 \%$ agarose (SeaKem FMC) solution in water was pipetted onto a $75 \times 25 \times 1-\mathrm{mm}$ objective slide. The coated slide was left to solidify and dry in the open air at room temperature for 10 min. A 5- $\mu$ l drop of cell suspension was placed on the surface of 
the agarose and immediately covered with a coverslip. Image grabbing and processing was performed as described previously (Lewis and Errington 1996), except for Figure 2, panels I and J, which were done as described above. Exposure times were $4 \mathrm{sec}$ for GFP and $300 \mathrm{msec}$ for phase contrast.

To test the requirement for initiation of DNA replication in duplication of SpoOJ foci, tetracycline $(20 \mu \mathrm{g} / \mathrm{ml})$ was added 40 min before immobilizing and observing the cells.

\section{Cell cycle analysis}

The microscopic methods of Hauser and Errington (1995) were used to determine the cell length, nucleoid number, and DNA content of individual cells. The program OBJECT-IMAGE (Vischer et al. 1994) was used to facilitate collection of the data. The average cell length and DNA content at division was calculated by use of a computer algorithm based on the work of Collins and Richmond (1962) (P.M. Hauser, M.E. Sharpe, R.G. Sharpe, and J. Errington, unpubl.). Given that the time for completion of a round of DNA replication is almost constant at reasonably rapid growth rates $(-55 \mathrm{~min}$; Ephrati-Elizur and Borenstein 1971; Dunn et al. 1978; Hauser and Errington 1995; P.M. Hauser, M.E. Sharpe, R.G. Sharpe, and J. Errington, unpubl.), the cell length at initiation of DNA replication can be calculated (Collins and Richmond 1962; P.M. Hauser, M.E. Sharpe, R.G. Sharpe, and J. Errington, unpubl.). The average number of copies of oriC per cell can then be derived from the measured cell length/frequency distributions. At all growth rates measured, the average cell length at initiation of DNA replication was close to $1.2 \mu \mathrm{m}$ (per chromosome-in these experiments the cells contain two or four replicating chromosomes), in accordance with the concept of constancy of the initiation mass (Donachie 1968).

\section{Thymine deprivation experiments}

Strain 1723 (trpC2 thy $A B$ spo0T-gfp) was constructed by transforming a thy $A B$ mutant with chromosomal DNA from strain 1510 and selection for chloramphenicol resistence. Strain 1723 was grown at $30^{\circ} \mathrm{C}$ in SMMX containing thymine $(15 \mu \mathrm{g} / \mathrm{ml})$ to an $\mathrm{OD}_{600}$ of 0.5 . The culture was divided into two portions: One was centrifuged, washed, and resuspended in fresh medium containing thymine; the other in medium devoid of thymine. The cultures were incubated for an additional $2 \mathrm{hr}$ before being examined either on agarose-coated slides or after glutaraldehyde fixation and DAPI staining (as described above).

\section{Behavior of SpoOJ-GFP in a divIB mutant}

divIB null mutants are temperature sensitive for cell division (Beall and Lutkenhaus 1989; Harry et al. 1993) and make significantly elongated cells at a temperature $\left(37^{\circ} \mathrm{C}\right)$ at which the Spo0J-GFP foci are still visible. Plasmid pAF014 (A. Feucht, unpubl.) is a derivative of $\mathrm{p} 8 \Delta \mathrm{Ecm}$ (Beall and Lutkenhaus 1989) in which the chloramphenicol resistance cassette inserted into divIB has been replaced with a spectinomycin resistance determinant. This plasmid was transformed into strain 1510 with selection for resistance to spectinomycin (and chloramphenicol, to retain the spo0/-gfp fusion plasmid). The resultant strain (1408) was grown at $30^{\circ} \mathrm{C}$ in SMMX to an $\mathrm{OD}_{600}$ of 0.7 , then shifted to $37^{\circ} \mathrm{C}$ for $30 \mathrm{~min}$, to induce filamentation, before viewing.

\section{Acknowledgments}

We thank Andrea Feucht and Alan Grossman for providing strains or plasmids; Peter Lewis and Ling Juan Wu for helpful comments on the manuscript; and Dane Mohl and Jim Gober for communicating results before publication. P.G. was the recipient of an EMBO Fellowship. Work in the J.E. lab was funded by the Biotechnology and Biological Sciences Research Council. B.R., M.P., and K.O. were supported by the National Institute of General Medical Sciences, N.I.H., U.S. Public Health Service.

The publication costs of this article were defrayed in part by payment of page charges. This article must therefore be hereby marked "advertisement" in accordance with 18 USC section 1734 solely to indicate this fact.

\section{References}

Beall, B. and J. Lutkenhaus. 1989. Nucleotide sequence and insertional inactivation of a Bacillus subtilis gene that affects cell division, sporulation, and temperature sensitivity. $J$. Bacteriol. 171: 6821-6834.

Begg, K.J. and W.D. Donachie. 1991. Experiments on chromosome separation and positioning in Escherichia coli. New Biol. 3: 475-486.

Bylund, J.E., M.A. Haines, P.J. Piggot, and M.L. Higgins. 1993. Axial filament formation in Bacillus subtilis: Induction of nucleoids of increasing length after addition of chloramphenicol to exponential-phase cultures approaching stationary phase. I. Bacteriol. 175: 1886-1890.

Collins, J.F. and M.H. Richmond. 1962. Rate of growth of $\mathrm{Ba}$ cillus cereus between divisions. J. Gen. Microbiol. 28: 15-23.

Donachie, W.D. 1968. Relationship between cell size and time of initiation of DNA replication. Nature 219: 1077-1079.

Dunn, G., P. Jeffs, N.H. Mann, D.M. Torgersen, and M. Young. 1978. The relationship between DNA replication and the induction of sporulation in Bacillus subtilis. J. Gen. Microbiol. 108: 189-195.

Ephrati-Elizur, E. and S. Borenstein. 1971. Velocity of chromosome replication in thymine-requiring and independent strains of Bacillus subtilis. J. Bacteriol. 106: 58-64.

Errington, J. and J. Mandelstam. 1986. Use of a lacZ gene fusion to determine the dependence pattern of sporulation operon spoIIA in spo mutants of Bacillus subtilis. I. Gen. Microbiol. 132: $2967-2976$

Harlow, E. and D.P. Lane. 1988. Antibodies: A laboratory manual. Cold Spring Harbor Laboratory, Cold Spring Harbor, NY.

Harry, E.J., B.J Stewart, and R.G. Wake. 1993. Characterization of mutations in divIB of Bacillus subtilis and cellular localization of the DivIB protein. Mol. Microbiol. 7: 611-621.

Hauser, P.M. and J. Errington. 1995. Characterization of cell cycle events during the onset of sporulation in Bacillus subtilis. I. Bacteriol. 177: 3923-3931.

Hiraga, S. 1993. Chromosome partition in Escherichia coli. Curr. Opin. Genet. Dev. 5: 789-801.

Hiraga, S., H. Niki, T. Ogura, C. Ichinose, H. Mori, B. Ezaki, and A. Jaffé. 1989. Chromosome partitioning in Escherichia coli: Novel mutants producing annucleate cells. J. Bacteriol. 171: 1496-1505.

Hiraga, S., T. Ogura, H. Niki, C. Ichinose, and H. Mori. 1990. Positioning of replicated chromosomes in Escherichia coli. J. Bacteriol. 172: 31-39.

Hoch, J.A. 1993. Regulation of the phosphorelay and the initiation of sporulation in Bacillus subtilis. Annu. Rev. Microbiol. 47: 441-465.

Holmes, M., M. Rickert, and O. Pierucci. 1980. Cell division cycle of Bacillus subtilis: Evidence of variability in period D. J. Bacteriol. 142: 254-261.

Hyman, A.A. and P.K. Sorger. 1995. Structure and function of kinetochores in budding yeast. Annu. Rev. Cell. Dev. Biol. 11: 441-465. 
Ireton, K., N.W. Gunther IV, and A.D. Grossman. 1994. spo0/ is required for normal chromosome segregation as well as the initiation of sporulation in Bacillus subtilis. I. Bacteriol. 176: $5320-5329$.

Karamata, D. and J.D. Gross. 1970. Isolation and genetic analysis of temperature-sensitive mutants of Bacillus subtilis defective in DNA synthesis. Mol. \& Gen. Genet. 108: 277-287.

Lewis, P.J. and J. Errington. 1996. Use of green fluorescent protein for detection of cell-specific gene expression and subcellular protein localization during sporulation in Bacillus subtilis. Microbiology 142: 733-740.

Lewis, P.J., T. Magnin, and J. Errington. 1996. Compartmentalized distribution of the proteins controlling the presporespecific transcription factor $\sigma^{\mathrm{F}}$ of Bacillus subtilis. Genes Cells 1: 881-894.

Lin, D.C.-H., P.A. Levin, and A.D. Grossman. 1997. Bipolar localization of a chromosome segregation protein in Bacillus subtilis. Proc. Natl. Acad. Sci. (in press).

McGinness, T. and R.G. Wake. 1979. Division septation in the absence of chromosome termination in Bacillus subtilis. $I$. Mol. Biol. 134: 251-264.

Mohl, D.A. and J.W. Gober. 1997. Cell cycle-dependent polar localization of chromosome partitioning proteins in Caulobacter crescentus. Cell 88: 675-684.

Mysliwiec, T.H., J. Errington, A.B. Vaidya, and M.G. Bramucci. 1991. The Bacillus subtilis spoof gene: Evidence for involvement in catabolite repression of sporulation. I. Bacteriol. 173: 1911-1919.

Niki, H., A. Jaffé, R. Imamura, T. Ogura, and S. Hiraga. 1991. The new gene $m u k B$ codes for a 177 kd protein with coiledcoil domains involved in chromosome partitioning of $E$. coli. EMBO I. 10: 183-193.

Niki, H., R. Imamura, M. Kitaoka, K. Yamanaka, T. Ogura, and S. Hiraga. 1992. E. coli MukB protein involved in chromosome partition forms a homodimer with a rod-and-hinge structure having DNA binding and ATP/GTP binding activities. EMBO J. 11: 5101-5109.

Ogasawara, N. and H. Yoshikawa. 1992. Genes and their organization in the replication origin region of the bacterial chromosome. Mol. Microbiol. 6: 629-634.

Partridge, S.R. and J. Errington. 1993. The importance of morphological events and intercellular interactions in the regulation of prespore-specific gene expression during sporulation in Bacillus subtilis. Mol. Microbiol. 8: 945-955.

Pogliano, K., E. Harry, and R. Losick. 1995. Visualization of the subcellular location of sporulation proteins in Bacillus subtilisusing immunofluorescence microscopy. Mol. Microbiol. 18: 459-470.

Reznekov, O., S. Alper, and R. Losick. 1996. Subcellular localization of proteins governing the proteolytic activation of a developmental transcription factor in Bacillus subtilis. Genes Cells 1: 529-542.

Sargent, M.G. 1974. Nuclear segregation in Bacillus subtilis. Nature 250: 252-254.

Sharpe, M.E. and J. Errington. 1995. Postseptational chromosome partitioning in bacteria. Proc. Natl. Acad. Sci. 92: 8630-8634.

- 1996 . The Bacillus subtilis soj-spo0J locus is required for a centromere-like function involved in prespore chromosome partitioning. Mol. Microbiol. 21: 501-509.

Sterlini, J.M. and J. Mandelstam. 1969. Committment to sporulation in Bacillus subtilis and its relationship to the development of actinomycin resistance. Biochem. I. 113: 29-37.

van Helvoort, J.M.L.M. and C.L. Woldringh. 1994. Nucleoid partitioning in Escherichia coli during steady state growth and upon recovery from chloramphenicol treatment. Mol. Micro- biol. 13: $577-583$.

Vischer, N.O.E., P.G. Huls, and C.L. Woldringh. 1994. OBJECTIMAGE: An interactive image analysis program using structured point collection. Binary 6: 160-166.

Wake, R.G. and J. Errington. 1995. Chromosome partitioning in bacteria. Annu. Rev. Genet. 29: 41-67.

Williams, D.R. and C.M. Thomas. 1992. Active partitioning of bacterial plasmids. J. Gen. Microbiol. 138: 1-16.

Wu, L.J. and J. Errington. 1994. Bacillus subtilis SpoIIIE protein required for DNA segregation during asymmetric cell division. Science 264: 572-575.

Wu, L.J., P.J. Lewis, R. Allmansberger, P.M. Hauser, and J. Errington. 1995. A conjugation-like mechanism for prespore chromosome partitioning during sporulation in Bacillus subtilis. Genes \& Dev. 9: 1316-1326. 


\section{Erratum}

Genes \& Development 11: 1160-1168.

Dynamic, mitotic-like behavior of a bacterial protein required for accurate chromosome partitioning

Philippe Glaser, Michaela E. Sharpe, Brian Raether, Marta Perego, Kari Ohlsen, and Jeff Errington

The legend to Figure 2 in the above paper described the arrows incorrectly. The correct description appears below.

Thick arrows indicate examples of foci that duplicated during the period of incubation, and thin arrows indicate examples of pairs of foci that appeared to move apart al ong the long axis of the cell. 


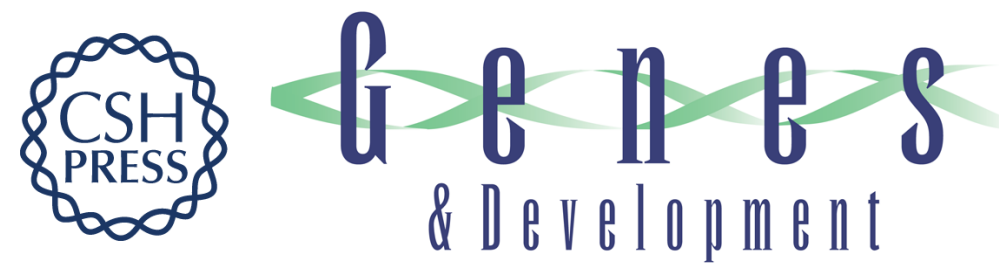

\section{Dynamic, mitotic-like behavior of a bacterial protein required for accurate chromosome partitioning.}

P Glaser, M E Sharpe, B Raether, et al.

Genes Dev. 1997, 11:

Access the most recent version at doi:10.1101/gad.11.9.1160

References This article cites 39 articles, 13 of which can be accessed free at:

http://genesdev.cshlp.org/content/11/9/1160.full.html\#ref-list-1

License

Email Alerting

Service

Receive free email alerts when new articles cite this article - sign up in the box at the top right corner of the article or click here.

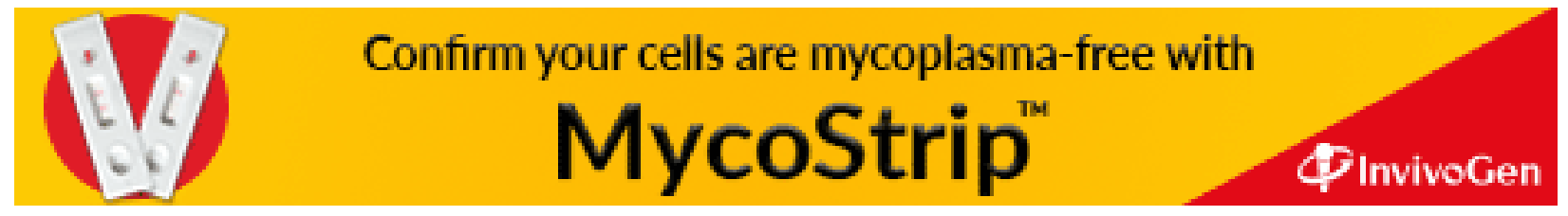

